\title{
Effect of cell immobilization on the treatment of olive mill wastewater by a total phenols, acetic acid and formic acid degrading bacterium strain
}

\author{
By Abdelghani El Asli ${ }^{1, *}$, Faouzi Errachidi ${ }^{2}$, Rhizlane Bennisse ${ }^{3}$ Abdel-illah Qatibi $^{3}$ and \\ Mohamed Errami ${ }^{4}$
}

\author{
${ }^{1}$ School of Science \& Engineering, Al Akhawayn University, Ifrane, Morocco(Fax: int + 212-55 567150; \\ E-mail: a.elasli@alakhawayn.ma \\ ${ }^{2}$ Faculté des Sciences, Université Sidi Mohamed Benabdellah, Fès, Morocco \\ ${ }^{3}$ Faculté des Sciences et Techniques, Université Cadi Ayyad, Marrakesh, Morocco \\ ${ }^{4}$ Faculté des Sciences, Université Abdelmalek Saadi,Tetuoan, Morocco
}

\section{RESUMEN}

Efecto de la inmovilización celular sobre el tratamiento del alpechín con una bacteria que degrada polifenoles y los ácidos acéticos y fórmico.

El alpechín (OMW) es un residuo puro de la extracción del aceite de oliva, que contiene una elevada carga orgánica y de polifenoles por lo que es resistente a la degradación. Su descarga produce graves problemas de contaminación medioambiental en toda el área mediterránea. Se ha aislado una bacteria anaerobia del OMW, que , durante tres ciclos consecutivos de tratamiento del OMW diluido y suplementado, produjo una disminución significativa de las sustancias fitotóxicas del residuo. De hecho, la concentración en fenoles totales, ácido acético y ácido fórmico se redujeron entre 33 y $64 \%$ cuando las células no estaban inmovilizadas y entre el 62 y $78 \%$ cuando las células bacterianas se inmovilizaron en una esponja de poliuretano. Estos resultados indican que el cultiva de la nueva bacteria aislada puede disminuir la fototoxicidad el alpechín. Análisis filogenético del ribosoma 16S de DNA demostró que todas las secuencias eran miembros de la familia Enterobacteriaceae y que la bacteria aislada podía identificarse como una cepa de Klebsiella oxytoca.

PALABRAS-CLAVE: Alpechín - Degradación anaeróbica Fenoles totales - Inmovilización - Klebsiella oxytoca.

\section{SUMMARY}

Effect of cell immobilization on the treatment of olive mill wastewater by a total phenols, acetic acid and formic acid degrading bacterium strain.

Olive mill wastewater (OMW) is a pure vegetative by-product, containing a high organic and polyphenol content and is resistant to biodegradation. Its disposal lead to major environmental pollution problems in the Mediterranean basin. An aerobic bacterium was isolated from OMW. During three consecutive diluted and supplemented OMW treatment cycles, significant abatement of its phytotoxic substances was observed. In fact, total phenols, acetic and formic acids were reduced between 33 and $64 \%$ when cells of the isolated bacterium were grown free; and between 62 and $78 \%$ when cells of the same isolated bacterium were grown immobilized in a polyurethane sponge. These results suggest that the bacterium culture of the new isolate would decrease the OMW phytotoxicity. Phylogenetic analysis of $16 \mathrm{~S}$ ribosomal DNA showed that all the related sequences are members of the Enterobacteriaceae family and revealed that the isolated bacterium was characterized as a Klebsiella oxytoca strain

KEY-WORDS: Aerobic degradation - Immobilization Klebsiella oxytoca - Olive mill wastewater - Total phenol.

\section{INTRODUCTION}

A volume of $3.10^{7} \mathrm{M}^{3}$ per year is generated by the olive oil industry in the Mediterranean area as aqueous by-products of olive oil separation (Sayadi, \& Ellouz, 1995). OMW is a dark colored, mildly acidic liquid. The main toxicity of this effluent is related to its phenolic constituents, with a concentration range that may vary from $1.5 \mathrm{~g}$ up to $10 \mathrm{~g} / \mathrm{l}$. Another relevant problem attributed to this effluent is its strong dark color, which is mainly due to chromophoric lignin-related materials with different degrees of polymerization (Sayadi, \& Ellouz, 1995). Because of the high organic and polyphenol content of OMW, its direct disposal may pollute both land and aquatic environments (Moreno et al., 1990; Capasso et al., 1992). Antibacterial activity, inhibition of seed germination and phytotoxicity to herbage crops by OMW have been demonstrated (Paixao et al., 1990).

OMW contains no xenobiotics or heavy metal contaminants and its application to soil of low organic matter content, abundant in the Mediterranean basin, would be a sustainable recycling option, if its toxicity to microorganisms and plants was first eliminated. The phytotoxicity of OMW is due to the phenolic substances and some organic acids such as acetic and formic acid (Piperidou et al., 2000). The inorganic constituents at the concentration levels found in OMW are not toxic. In fact, it has been proven that they may potentially act as good sources of plant nutrients (Piperidou et al., 2000).

Great attention has been given to the biological treatment of $\mathrm{OMW}$ as an alternative to the conventional treatment processes. However, OMW inhibits several groups of bacteria and fungal species (Ramos-Cormenzana et al., 1996), thus affecting both the aerobic and the anaerobic treatment methods (Maestro et al., 1991).

The toxicity of phenols is significantly reduced when micro-organisms are grown in immobilized form (Keweloh et al., 1989). The OMW treatment with polyurethane-immobilized Lentinula edodes resulted 
in an overall abatement of phenolic and aromatic components (D'Annibale et al., 1998).

In the present study, a total phenols, acetic acid and formic acid-degrading bacterium was isolated from the wastewater of an olive mill. In addition to the identification of the isolated bacterium with $16 \mathrm{~S}$ rDNA approach, we have investigated consecutive OMW treatment cycles with immobilized cells of the isolated bacterium in a polyurethane sponge

\section{MATERIALS AND METHODS}

\subsection{Microorganisms and inoculum preparation}

Various bacteria were isolated from the wastewater of a local olive mill and screened for total phenols, acetic acid and formic acid degradation. Strain EA62 was found to degrade total phenols, acetic acid and formic acid. Colonies, grown on agar plates, were inoculated into a $5 \mathrm{ml}$ YEPG medium (yeast extract $\left(5 \mathrm{~g} \mathrm{I}^{-1}\right)$, peptone $\left(20 \mathrm{gl}^{-1}\right)$ and glucose $\left.\left(25 \mathrm{~g} \mathrm{l}^{-1}\right)\right)$ and incubated for $16 \mathrm{~h}$ at $37{ }^{\circ} \mathrm{C}$ with shaking at $200 \mathrm{rpm}$. The isolated bacterium was routinely subcultured on 'YEPG' agar slant. EA62 characterization was performed in this work using the API 20 E system (Montalieu Vercieu, France). Its genes encoding for $16 \mathrm{~S}$ rDNA were amplified and sequenced as described in the next section

\subsection{Phylogenetic Analysis}

A single colony of the isolated bacterium was heated in a microwave oven for 90 seconds and used as such for PCR amplification of almost-full length bacterial 16S rDNA. The retrieved amplificates were analyzed by electrophoresis in 1\% (w/v) agar gel and staining with ethidium bromide. DNA purification was done with the QIAquick PCR Purification Kit and the QIAEX II Gel Extraction Kit from Qiagen 16S rDNA was sequenced with Cycle-Sequencing with fluorescent dye terminator technology and the ABI PrismTM analysis system 377 by SEQLAB Sequence Laboratories $\mathrm{GmbH}$. Sequence analyses of the $16 \mathrm{~S}$ rDNA were performed by using the European Bioinformatics Institute (EBI) website (HYPERLINK http://www.ebi.ac.uk/) http:// www.ebi.ac.uk/). Related sequences were obtained by using the fasta 3.0 search programs (Pearson and Lipman, 1988). Then, the sequences were aligned and phylogenetic distances were calculated by using the CLUSTALW algorithm Thompson et al, 1994), and phylogenetic trees were drawn by using the Tree View program (Win 32; Division of Environmental and Evolutionary Biology, Institute of Biomedical and Life Sciences, University of Glasgow (HYPERLINK http://taxonomy.zoology.gla.ac.uk/ $\mathrm{rod} /$ treeview.html Nucleotide sequence accession number. The $16 \mathrm{~S}$ rDNA sequence described above was deposited under GenBank accession number AF 319525.

\subsection{Immobilization of strain EA62}

A polyurethane sponge (0.4-0.6 $\mathrm{mm}$ pore size) was cut into $1.2-\mathrm{cm}$ cubes, which were washed and autoclaved in deionized water before use as described elsewhere (D'Annibale et al, 1998). Cultures for immobilization contained $301.2-\mathrm{cm}$ cubes of sponge (1.38 $\mathrm{g}$ dry weight) autoclaved in $200 \mathrm{ml}$ of the medium used for the inoculum in 2-I Erlenmeyer flasks. Inoculation was performed with $5 \mathrm{ml}$ of inoculum and cultures were incubated at $37^{\circ} \mathrm{C}$ on a gyratory shaker (200 rpm; $2.5 \mathrm{~cm}$ radius) for up to 5 days until the surface of the sponge appeared to be uniformly colonized, as determined by visual inspection. The average immobilization yield was $6 \%(\mathrm{w} / \mathrm{w})$ as estimated by gravimetric analysis (Kirkpatrick et al, 1990).

\subsection{Aerobic Treatment of Olive Mill Waste Water}

Diluted olive mill wastewater (13 folds) was centrifuged (11000 x g, $30 \mathrm{~min})$, supplemented with saccharose $\left(10 \mathrm{~g} \mathrm{l}^{-1}\right)$ and yeast extract $\left(1 \mathrm{~g} \mathrm{l}^{-1}\right)$ and filter-sterilized $(0.2 \mathrm{~m})$. Then aerobic treatment of OMW was performed by repeated batch fermentation in a 2-1 Erlenmeyer flask containing immobilized cells of the tested micro-organism using the following standard conditions: effluent $300 \mathrm{ml}$, temperature $37^{\circ} \mathrm{C}$, orbital shaking $(30 \mathrm{rpm} ; 2.5 \mathrm{~cm}$ radius), treatment time 7 days for each batch. Under these conditions, the cultures were purged daily (10 $\mathrm{min}$ ) with filter sterilized oxygen. After each batch the carrier was washed three times with deionized water and supplemented-OMW was again added. All the results were obtained using triplicate cultures. Because of difficulties encountered in the acetic acid and formic acid analysis in the treated OMW, the degradation of the two acids was conducted separately from the OMWW but under the same conditions in a synthetic medium made of YEP (yeast extract $\left(10 \mathrm{~g} \mathrm{l}^{-1}\right)$ and peptone $\left.\left(20 \mathrm{~g} \mathrm{l}^{-1}\right)\right)$ supplemented with acetic acid and formic acid. The initial concentrations of both acids used in the synthetic medium (YEP) for their biodegradation were obtained from the work of Piperidou (2000).

Both media OMW and YEP supplemented with the acetic acid and the formic acid were added to the support polyurethane sponge in the absence of the micro-organism under the same conditions employed for the biological treatment as a control.

\subsection{Analytical methods}

Total phenols were determined according to a modification of the Folin-Ciocalteau method (Swain 
and Hillis., 1959). Acetic acid and formic acid were quantified with simple titration using their corresponding $\mathrm{Ka}$.

\section{RESULTS}

\subsection{Characterization of the EA62 strain}

Strain EA62 isolated from olive mill wastewater in Morocco was found to be Gram-negative, straight rods, $0.6 \mathrm{~m}$ wide and 3.0-5.0 $\mu \mathrm{m}$ long, occurring individually, or in pairs, capsulated, non-motile, very large circular, flat and mucoid colonies, up to $8 \mathrm{~mm}$ in diameter, beige with irregular crenated edges. They were found to have both a respiratory and a fermentative type of metabolism. Optimum growth was at $37^{\circ} \mathrm{C}$; no growth was observed below $20^{\circ} \mathrm{C}$ or above $45^{\circ} \mathrm{C}$. Optimum pH for growth was 6.3 with a range between 5.0 and 8.0. Positive tests were conducted for $\beta$-galactosidase, lysine decarboxylase, indole production and urease; while they tested negative for Oxidase, arginine dihydrolase, ornithine decarboxylase, Simmons citrate, $\mathrm{H}_{2} \mathrm{~S}$ production, tryptophan deaminase, and gelatinase. They ferment the following compounds: amygdaline, L-arabinose, D-glucose, inositol, mannitol, rhamnose, sorbitol, sucrose, and D-xylose. Compounds not fermented were melibiose.

On the basis of these results, the API $20 \mathrm{E}$ classified it as Klebsiella strain with very low discrimination. In order to better clarify the taxonomy of this strain, the nucleotide sequence of its $16 \mathrm{~S}$ rDNA was determined and compared with related sequences that were obtained using the fasta 3.0 search program (Pearson and lipman, 1998). The matrix obtained was used to draw a phylogenetic tree. As shown in figure 1, the EA62 strain was positioned in the Klebsiella group. Considering the alignment positions used to draw the tree, strain EA62 shared similarity values of (99.11 to $99.9 \%$ similarity) with strains of $K$. oxytoca. The highest similarity values $(99.9 \%)$ were shared with $K$. oxytoca (ATCC 13182- U78183).

\subsection{Removal of acetic acid, formic acid and phenolic constituents}

Diluted olive mill wastewater (13 folds), whose raw composition is shown in table 1 , were subjected to aerobic treatment with strain EA62 previously immobilized on a polyurethane sponge. Figure 3 shows that during consecutive and separate treatment cycles of OMW and synthetic medium, the phytotoxic substances of OMW (total phenols, acetic and formic acids) were reduced between 33 and $64 \%$ when cells of the isolated bacterium are grown free. Figure 2 reports the biodegradation of total phenols, acetic acid and formic acid by immobilized strain EA62. The three batches showed a high capability in the depletion of acetic acid and formic acid. However, only the first two batches reported a considerable biodegradation of total phenols. The rate of decrease in acetic acid and formic acid concentrations was nearly constant and with the same extent for both acids. In the first cycle the removal of acetic acid was 62 $\%$ and formic acid was $65 \%$, while in the subsequent experiments $63 \%$ and $62 \%$ of acetic acid reduction and $70 \%$ and $60 \%$ of formic acid reduction was reported. It seems that the removal rate of both acids was independent of the concentration of the residual acids. The detoxifying capability was further confirmed by the trend of the total phenols content. In fact, the removal efficiency of total phenols reached maximum values of $78 \%, 61 \%$ and $30 \%$, respectively in the 3 batches. The phenol removal was rapid during the first two batches.

The concentration of the tested compounds in the sterile controls did not appreciably change with

Table 1

Composition and features of the untreated raw olive mill wastewater

\begin{tabular}{lc}
\hline Parameter & Untreated olive mill wastewater \\
\hline & \\
pH & 5 \\
DCO & $145\left(\mathrm{O}_{2}\right)$ \\
DBO & $60\left(\mathrm{O}_{2}\right)$ \\
Total phenols & 8.7 \\
Total sugars & 1.8 \\
$\mathrm{Ca}^{2+}$ & 0.3 \\
$\mathrm{Na}^{+}$ & 0.60 \\
$\mathrm{~K}^{+}$ & 0.3 \\
$\mathrm{Fe}^{2+}$ & 0.04 \\
\hline
\end{tabular}

All concentration are expressed in $\mathrm{g} / \mathrm{l}$ 


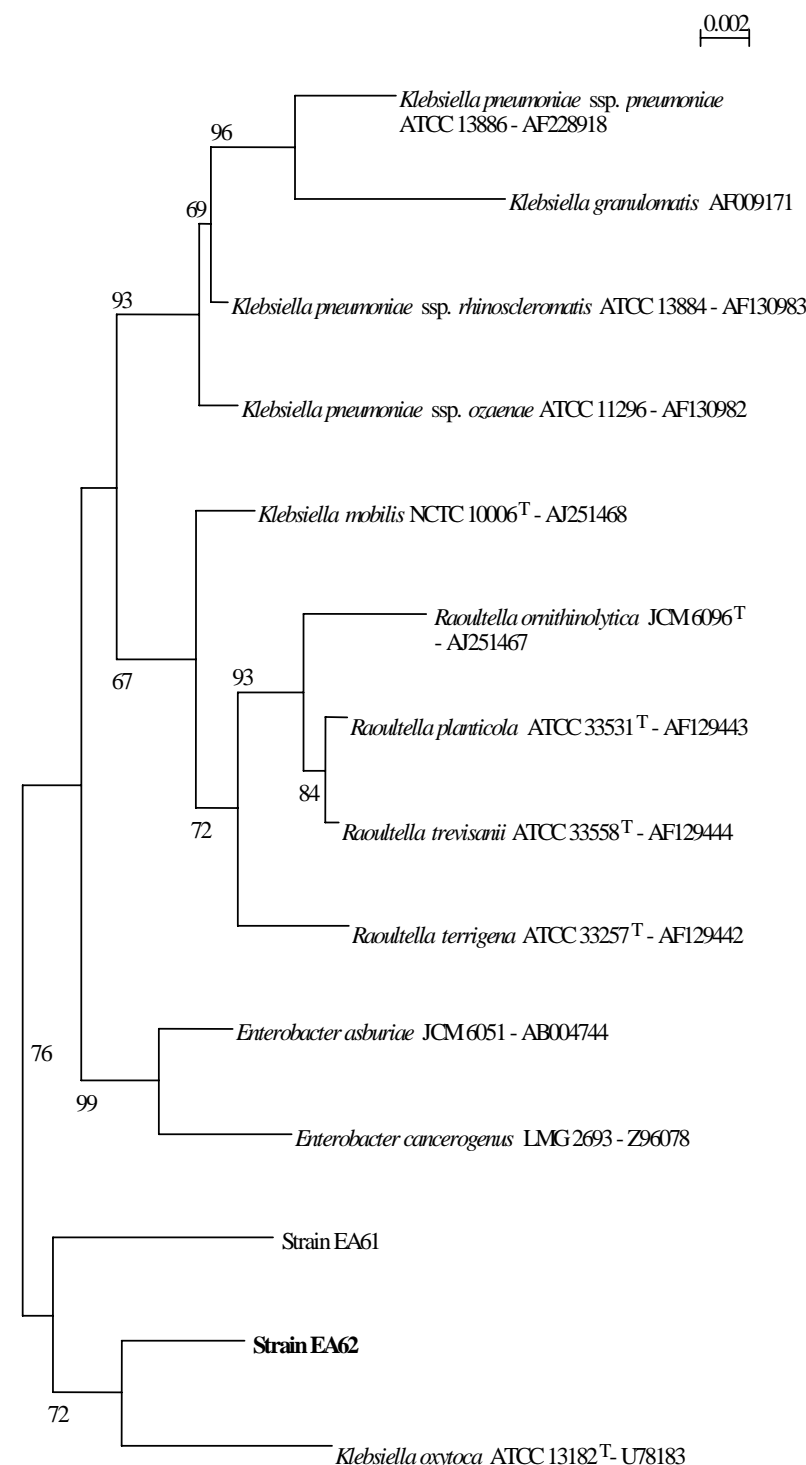

Figure 1

Unrooted phylogenetic dendrogram based on 16S rRNA sequence data indicating the position of strain EA62. Numbers at the branching points refer to bootstrap values $>85 \%$ (1000 reesamplings). Accession numbers of $16 \mathrm{~S}$ rRNA gene sequences are given in parentheses. Bar, $\mathbf{X}$ nucleotides substitutions per 1000 nucleotides.

incubation time, except for the acetic acid which was found to slowly disappear in the culture (data not shown).

\section{DISCUSSION}

The OMW composition may vary according to cultivar, harvesting time, health of the olives, and technology used in the extraction process. The phytotoxicity of OMW is linked to the phenolic substances and some organic acids such as acetic and formic acid, which are often produced along with other microbial metabolites during storage (Piperidou et al, 2000). This great diversity of organic

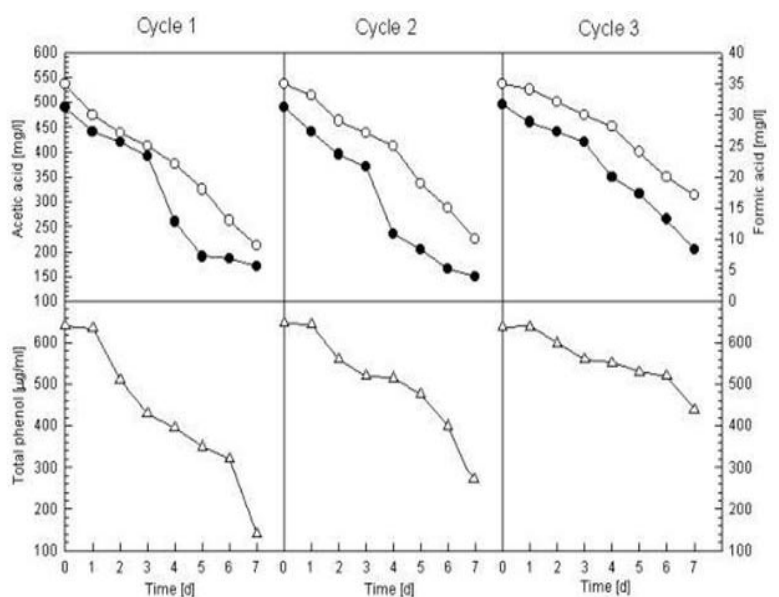

Figure 2

Total phenols $(\Delta)$, acetic acid $(0)$, and formic acid $(\bullet)$ content during three consecutive treatment cycles of olive mill wastewater by immobilized Klebsiella oxytoca. EA62 strain. The waste was supplemented with saccharose $\left(10 \mathrm{~g} \mathrm{I}^{-1}\right)$, and yeast extract $\left(1 \mathrm{~g} \mathrm{I}^{-}\right.$ $\left.{ }^{1}\right)$. Measurements were done in triplicate and the deviations from the average values were less than $10 \%$.

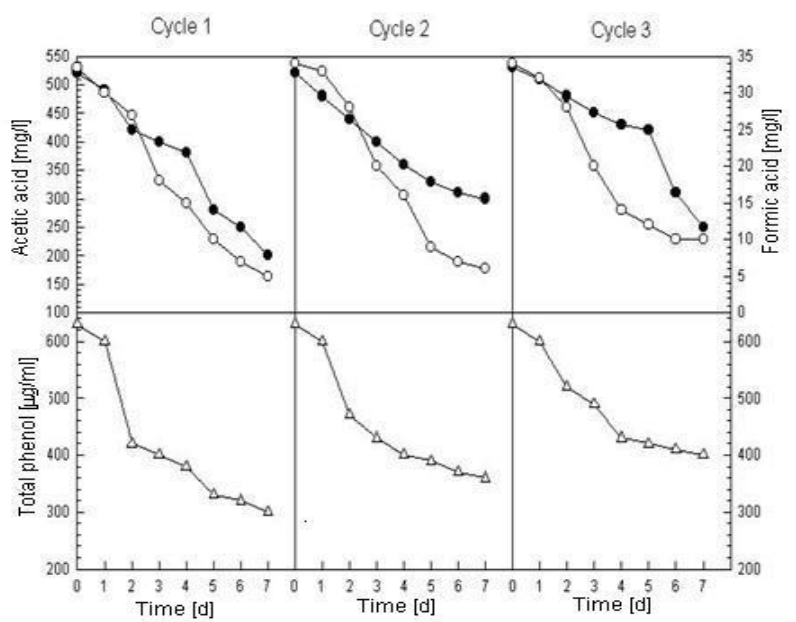

Figure 3

Change in total phenols $(\Delta)$, acetic acid $(0)$, and formic acid $(\bullet)$ content during three consecutive treatment cycles of olive mill wastewater by free Klebsiella oxytoca EA62 strain. The waste was supplemented with saccharose $\left(10 \mathrm{~g} \mathrm{I}^{-1}\right)$, and yeast extract $\left(1 \mathrm{~g} \mathrm{l}^{-1}\right)$. Measurements were done in triplicate and the deviations from the average values were less than $10 \%$.

acids and phenolic compounds in OMW deserves a special consideration during the bioremediation of OMW into the processed OMW (biofertilizer). We attempted to isolate and characterize a bacterium strain from OMW and to study its capability in degrading the main phytotoxic substances of OMW; this is the first step of a research project focused on the development of a biotechnological process for the removal of these phytotoxic compounds from OMW. 
Strain EA62, which is capable of removing total phenols, as well as degrading both acetic and formic acids, was isolated from olive mill wastewater. Phylogenetic analysis, based on the comparison of the 16S rDNA sequence of strain EA62, with a database of $16 S$ rDNA sequences, showed that all the related sequences are members of the Enterobacteriaceae family. The isolated bacterium, strain EA62, was characterized as a K. oxytoca strain.

The toxic effect related to total phenols at concentrations higher than $640-650 \% \mathrm{~g} / \mathrm{ml}$ affected the degradative performances of the K. oxytoca. The data obtained have shown that the bioremediation of OMW with immobilized EA62 resulted in a considerable abatement of total phenolic compounds. Total phenols, acetic and formic acids were reduced between 33 and $64 \%$ when cells of the isolated bacterium were grown free and between 62 and $78 \%$ when cells of the same isolated bacterium were grown immobilized in a polyurethane sponge. This toxicity of phenol is significantly reduced when micro-organisms are grown immobilized (Keweloh et al, 1989). The reason for this change in the behavior of immobilized or adherent microbial cells is unknown. Probably, physiological alterations of cells are part of a cell aggregate, such as a colony protecting the microorganisms against the toxic action of phenolic compounds (Keweloh et al, 1989; Mattiasson et al, 1984). Pseudomonas aeruginosa tolerated phenol concentrations of up to $1 \mathrm{mg} / \mathrm{L}$ and has a maximum phenol activity of $350 \mathrm{mg} / \mathrm{L}$ x day -1 under aerobic conditions (Son et al, 1999).

The best biodegradative results were obtained in the first and the second batches. During the first day of each cycle, the removal of phenols was insignificant; however, the depletion of both acids is considerable. Therefore, it appeared that the biodegradative metabolism of phenols is not tightly connected with the biodegradative metabolism of acetic and formic acids. Total phenols have been found to decrease from 1500 to $250 \mu \mathrm{g} / \mathrm{ml}$ in three consecutive OMW treatments with an immobilized $L$. edodes (D'Annibal et al, 1998). The darkening of the immobilized biomass at the end of the third batch indicated that the limit of the system's lifetime should be 21 days. It should be taken into account that the average immobilization yield of the isolated bacterium in a polyurethane sponge $(6 \%(\mathrm{w} / \mathrm{w}))$ was lower than the one obtained with the white-rot fungus L. edodes (8\% (w/w)) (D’Annibal et al, 1998).

\section{ACKNOWLEDGEMENTS}

We would like to sincerely thank Dr. C. Hollenberg and Dr. E. Boles (Institute of Microbiology, Heinreich-Heine-Universität, Dusseldorf, Germany) for their help in amplification, sequencing of the $16 S$ rDNA and taxonomical analysis of the isolated EA62 strain.

\section{REFERENCES}

Capasso R., Cristinzio I., Evidente A., Scognamiglio F. 1992. Isolation, spectroscopy and selective phytotoxic effects of polyphenols from vegetable wastewaters. Phytochemistry 31, 4125-4128.

D’Annibale A., Crestini C., Vinciguerra V., Sermani G.G. 1998. The biodegradation of recalcitrant effluents from an olive mill by a white-rot fungus. Journal of Biotechnology 61 209-218.

Keweloh H., Heipieper HJ., Rehm HJ. 1989. Protection of bacteria against toxicity of phenol by immobilization in calcium alginate. Appl Microbiol Biotechnol 31, 383-389.

Kirkpatrick N., Reid I.D., Ziomek, Paice M.G. 1990. Biological bleaching of hardwood Kraft pulp using Trametes versicolor immobilzed in polyurethane foam. Appl. Microbiol. Biotechnol. 33, 105-108.

Maestro D., Borja P. R., Martin M. A., Fiestas Ros de Ursinos J. A. 1991. Biodegradacion de los compuestos fenolicos presentes en alpechin. Grasas Aceites 42, 271-276.

Mattiasson B., Larsson M., Hahn-Hagerdal B. 1984. Metabolic behavior of immobilized cells - effects of some microenvironmental factors. Ann NY Acad. Sci. Enz. Eng. 7, 475-478.

Moreno E., Quevedo-Sarmiento J., Ramos-Cormenzana A. 1990. Antimicrobial activity of wastewater from olive oil mils. In Hazardous Waste Containment and Treatment; Cheremisinoff, P. N., Ed.; Gulf Publication : USA, Vol IV, pp 731-757.

Paixao, S. M., Mendoca, E., Picado A.; Anselmo, A. M. 1990. Acute toxicity evaluation of olive mill wastewater: A comparative study of three aquatic organisms. Environ. Toxicol 14, 263-269.

Pearson W. R., Lipman D. J. 1988. Improved tools for biological sequence comparison. Proc. Natl. Acad. Sci. USA 85, 2444-2448.

Piperidou C.I., Chaidou C. I., Stalikas C. D., Soulti K. Pilidis G. A., Balis C. 2000. Bioremediation of olive Mill Wastewater: Chemical alterations Induced by Azotobacter vineladii. J. Agric. Food. Chem. 48: 1941-1948.

Ramos-Cormenzana A., Juarez-Jimenez B., Garcia-Pareja M. P. 1996. Antimicrobial activity of olive mill wastewater. Int. Biodeterior. Biodegrad 38, 283-290.

Sayadi S., Ellouz R. 1995. Roles of lignin peroxidase and manganese peroxidase from Phanerochaete chrysosporium in the decolorization of the olive mill wastewater. Appl. Environ. Microbiol. 61, 1098-1103.

Swain T., Hillis W.E. 1959. The quantitative analysis of phenolic constituents of Prunus domestica. J. Sci. Food Agric 10, 63-68.

Thompson J. D., Higgins D. G., Gibson T. J. 1994. Clustal W: improving the sensivity of progressive multiple sequence alignment through sequence weithing, position -specific gap penalties and weight matrix choice. Nucleic acids Res 22, 4673-4680. 